\title{
Validation of a Questionnaire on ICTs (Information and Communication Technologies) Skills of Undergraduate Health Students in Brazil*
}

\author{
Andreia Araujo Lima Torres, Gardênia da Silva Abbad, Kelb Bousquet Santos \\ Universidade de Brasília, Brasília, Brazil
}

\begin{abstract}
The use of ICTs (information and communication technologies) is becoming more common in education, being viewed as one of the important strategies in training health care workers. As the use of ICT by students depends on their perception of easy level of use, among other factors, this paper presents the construction and statistical validation process of the ICTs scale. The instrument was applied to a sample of 244 freshmen students of five health courses, offered by a public university in Brazil. The scale aims to evaluate whether students felt able to use ICT if they were used as tools for learning. Data were collected by means of a questionnaire applied in person during the period of a week. Statistical analysis of the principal (PC), factorial (PAF), and internal consistency (Alpha Coefficient) components was performed. The scale presents a unifactorial structure, with 37 items, explaining $88.25 \%$ of the total variance, and Alpha coefficient of 0.977 . Results indicate a statistically valid and reliable scale. Further research in different education contexts is suggested.
\end{abstract}

Keywords: health education, factorial analysis, ICTs (information and communication technologies)

\section{Introduction}

There is a need for increasing the number of health care professionals all around the world (WHO (World Health Organization), 2007). As the quality of health care depends on the quantity and quality of staff (Brasil, 2003; WHO, 2006), it is expected that e-learning starts being even more used in order to guarantee a more equitable access to quality health services (WHO, 2013).

Advocates of ICTs (information and communication technologies) in education often regard them as capable of bringing positive changes in the teaching-learning process (Kozma, 2003; Kumar, 2009; Silveira et al., 2012). Thus differentiated instructional strategies can be implemented in order to reduce the imbalance between the skills of health professionals and the needs of the population (Westera, 2012).

Nevertheless the use of ICTs in education by students is not automatic, depending on their perception about the usefulness, quality, value (Chiu, Hsu, Sun, Lin, \& Sun, 2005) and ease of use of these technologies. It seems that students who use more technology tools are those who have prior knowledge about them

\footnotetext{
* This research was supported by CAPES.

Andreia Araujo Lima Torres, Ph.D. student, Universidade de Brasília.

Gardênia da Silva Abbad, Ph.D., professor, Psychology institute, Departamento de Psicologia Social e do Trabalho, Campus Darcy Ribeiro, Universidade de Brasília.

Kelb Bousquet-Santos, Ph.D., professor, Faculdade de Ceilândia, Universidade de Brasília.
} 
(Bennett, Bishop, Dalgarno, Waycott, \& Kennedy, 2012).

Therefore, some knowledge and skills on ICTs use need to be developed by students so that they can benefit from them (Lorenzo, Garcia, \& Murias, 2010). In order to know if Brazilian health freshmen students of a public university felt able to use ICTs if they were available as tools for learning, a questionnaire was applied and validated in 2012 .

\section{Method}

Quantitative study (Creswell, 2010) aimed to validate a scale to measure the easy level of use of ICT perceived by health students. The instrument was constructed by Guimarães (2013) to be used in corporate training contexts, from a review of 28 articles that examined self-efficacy in using computers. The questionnaire was adapted for this study and used with 37 items, associated with an 11-point scale, ranging from 0 to 10 ("Very easy" to "Very difficult"). The second part of the instrument contained questions aimed at gathering personal information (age, sex, course, semester, availability of computer, and Internet at home).

The application occurred in person during freshmen's classes resulting in the return of 244 questionnaires $(89.65 \%$ of students enrolled). After this time, the scale was subjected to factor analysis. Statistical analysis of the factorial consistency was performed using the factor analysis method (PAF) with Promax rotation.

The data analysis was performed using the IBM SPSS Statistics, version 20. The study was approved by the Ethics in Research Committee of the university in April 2012.

\section{Results}

Table 1 shows the characterization of 244 freshmen enrolled in the first semester of 2012. The campus offers five courses (nursing, pharmacy, physiotherapy, public health, and occupational therapy). The course that offers the largest number of vacancies is public health which reflects the higher number of students (24.59\%). Among all students $81.14 \%$ were female and $86.06 \%$ were 20 years old or less.

Table 1

Profile of Freshmen Enrolled of Five Health Courses in Brazil

\begin{tabular}{lcc}
\hline Variable & Frequency & Valid percent (\%) \\
\hline Course & & \\
Nursing & 45 & 18.44 \\
Pharmacy & 46 & 18.85 \\
Physiotherapy & 47 & 19.26 \\
Public health & 60 & 24.59 \\
Occupational therapy & 46 & 18.86 \\
Total & 244 & 100 \\
\hline Age & & \\
$\leq 17$ years old & 60 & 24.59 \\
18 to 20 years old & 150 & 61.47 \\
21 to 23 years old & 24 & 9.83 \\
$\geq 24$ years old & 10 & 4.11 \\
Sex & & \\
Female & 198 & 81.14 \\
Male & 46 & 18.86 \\
\hline
\end{tabular}

The value of KMO was 0.938 indicating an excellent factorability of the matrix. The Bartlett test of sphericity had a small significance level $(p<0.0001)$, indicating a low probability that the population matrix 
was an identity one. Visual inspection of the matrix showed that over $50 \%$ of the assumed correlation values were greater than 0.30 , also indicating the factorability of the matrix.

As in the study of Guimarães (2013), there were indications that the factor solution would be the best option. Thus, the analysis of the internal consistency of the scale-factor solution, all variables were grouped into a single factor. The reliability index (Cronbach's alpha) showed a value of 0.977 , with factor loadings ranging from 0.520 to 0.747 , ensuring the psychometric quality factor grouped. Considering Eigen values greater than 1.0 the total variance explained was $88.25 \%$. Thus, the instrument of ease/difficulty in the use of ICTs has been properly validated for this population, with 37 items about the general use of common tools and applications in computer use.

The results of the questionnaire are shown in Table 2.

Table 2

Responses to the Question: "How Hard Do You Consider the Handling of ICTs?"

\begin{tabular}{|c|c|c|c|c|c|c|}
\hline \multirow{2}{*}{ Items } & \multirow{2}{*}{ Missing } & \multirow{2}{*}{ Mean } & \multirow{2}{*}{$\begin{array}{l}\text { Standard } \\
\text { deviation }\end{array}$} & \multicolumn{3}{|c|}{ Valid percent (\%) } \\
\hline & & & & $0-3$ & $4-6$ & $7-10$ \\
\hline 1. Use a word editor to write texts & 0 & 1.26 & 2.129 & 89.2 & 6.1 & 4.7 \\
\hline 2. Print a document & 0 & 1.24 & 2.235 & 88.1 & 6.9 & 5.1 \\
\hline 3. Use the computer to organize information & 2 & 1.60 & 2.197 & 85.8 & 9.8 & 4.4 \\
\hline 4. Start a computer software & 0 & 1.48 & 2.201 & 87.7 & 6.1 & 6.1 \\
\hline 5. Delete files when they are no longer needed & 2 & 0.71 & 1.701 & 95.3 & 2.5 & 2.2 \\
\hline 6. Copy a file & 3 & 0.77 & 1.754 & 95.3 & 2.2 & 2.5 \\
\hline 7. Understand words and terms related to the use of Internet & 3 & 2.44 & 2.274 & 74.1 & 19.7 & 6.2 \\
\hline 8. Edit a file information & 0 & 1.96 & 2.275 & 82.3 & 11.2 & 6.5 \\
\hline 9. Use the Internet to fetch data & 1 & 1.09 & 1.916 & 92.4 & 4.3 & 3.3 \\
\hline 10. Ask question during a chat & 2 & 1.38 & 2.200 & 88.7 & 6.9 & 4.4 \\
\hline 11. Delete e-mail & 0 & 0.67 & 1.761 & 96.0 & 1.1 & 2.9 \\
\hline 12. Print e-mail & 1 & 0.96 & 1.989 & 92.4 & 4.3 & 3.3 \\
\hline 13. Send e-mail & 3 & 0.66 & 1.737 & 96.0 & 1.5 & 2.6 \\
\hline 14. Edit text before forwarding it & 2 & 1.17 & 2.075 & 89.8 & 6.5 & 3.6 \\
\hline 15. Attach a file to an e-mail message & 2 & 0.96 & 1.830 & 93.8 & 3.3 & 2.9 \\
\hline $\begin{array}{l}\text { 16. Find an e-mail from a particular sender or with a } \\
\text { specific subject }\end{array}$ & 1 & 1.50 & 2.121 & 87.0 & 8.0 & 5.1 \\
\hline 17. Save messages to a file & 4 & 2.02 & 2.194 & 78.4 & 16.5 & 5.1 \\
\hline 18. Change the password on websites & 1 & 1.46 & 2.155 & 87.3 & 8.3 & 4.3 \\
\hline 19. Communicate in chat rooms & 1 & 1.33 & 2.272 & 88.0 & 7.2 & 4.7 \\
\hline 20. Download a new software from the Internet & 1 & 2.13 & 2.564 & 74.3 & 17.8 & 8.0 \\
\hline $\begin{array}{l}\text { 21. Search certain terms or issues on the Internet using a } \\
\text { search engine tool }\end{array}$ & 3 & 1.18 & 2.014 & 89.8 & 6.6 & 3.6 \\
\hline $\begin{array}{l}\text { 22. Use advanced search parameters as logical operators } \\
\text { (and, or, not), filters, etc. }\end{array}$ & & 3.12 & 2.716 & 64.9 & 21.4 & 13.8 \\
\hline $\begin{array}{l}\text { 23. Communicate through forums (virtual communities of } \\
\text { discussion) on a subject of your interest }\end{array}$ & 0 & 2.06 & 2.433 & 77.6 & 14.8 & 7.6 \\
\hline 24. Talk to more than one person using the same screen & 0 & 1.17 & 2.173 & 89.9 & 4.7 & 5.4 \\
\hline 25. Chat on the Internet through audio (sound) & 2 & 1.76 & 2.370 & 83.6 & 9.5 & 6.9 \\
\hline $\begin{array}{l}\text { 26. Chat on the Internet through image and sound (webcam } \\
\text { or video) }\end{array}$ & 3 & 1.49 & 2.300 & 86.5 & 7.3 & 6.2 \\
\hline $\begin{array}{l}\text { 27. Send files to other people in a virtual learning } \\
\text { environment }\end{array}$ & 5 & 1.82 & 2.295 & 81.3 & 12.5 & 6.3 \\
\hline 28. Create a list of favorite pages for easy access & 3 & 1.53 & 2.250 & 81.2 & 14.2 & 3.6 \\
\hline
\end{tabular}


(Table 2 continued)

\begin{tabular}{|c|c|c|c|c|c|c|}
\hline \multirow{2}{*}{ Items } & \multirow{2}{*}{ Missing } & \multirow{2}{*}{ Mean } & \multirow{2}{*}{$\begin{array}{l}\text { Standard } \\
\text { deviation }\end{array}$} & \multicolumn{3}{|c|}{ Valid percent $(\%)$} \\
\hline & & & & $0-3$ & $4-6$ & $7-10$ \\
\hline 29. Find hyperlinks on web pages & 5 & 2.40 & 2.635 & 72.8 & 18.8 & 8.5 \\
\hline $\begin{array}{l}\text { 30. Install plugins (Flash, Shockwave, Java, etc.) required } \\
\text { to access documents, photos, videos, and webpages }\end{array}$ & 6 & 2.95 & 3.012 & 64.2 & 21.0 & 14.8 \\
\hline $\begin{array}{l}\text { 31. Access webpages using the standard navigation features } \\
\text { (forward, back, home, and reload buttons) }\end{array}$ & 3 & 1.22 & 2.256 & 87.6 & 7.7 & 4.7 \\
\hline $\begin{array}{l}\text { 32. Save files downloaded from the internet at specific } \\
\text { locations in the computer's hard drive }\end{array}$ & 3 & 1.65 & 2.579 & 82.1 & 10.9 & 6.9 \\
\hline $\begin{array}{l}\text { 33. Compress and decompress files using specific software } \\
\text { such as WinZip, WinRAR and others }\end{array}$ & 3 & 3.46 & 3.301 & 58.8 & 21.2 & 20.1 \\
\hline $\begin{array}{l}\text { 34. Configure audio options on your computer, enabling } \\
\text { and disabling the sound as needed }\end{array}$ & & 1.49 & 2.411 & 86.5 & 6.2 & 7.3 \\
\hline $\begin{array}{l}\text { 35. Evaluate which program is needed for opening files of } \\
\text { video and audio (avi, mpeg, mp3, etc.) }\end{array}$ & 4 & 2.72 & 2.951 & 68.1 & 18.7 & 13.2 \\
\hline 36. Install software & 3 & 2.52 & 2.838 & 70.1 & 19.0 & 10.9 \\
\hline 37. Convert text files from one extension to another & 3 & 3.88 & 3.180 & 53.3 & 25.9 & 20.8 \\
\hline
\end{tabular}

The descriptive results of the questionnaire showed that most participants did not consider difficult the skills addressed, regarding the use of ICTs, since all items showed a concentration of responses greater than $50 \%$ in grades 0 to 3 (the easier ones). The averages ranged from 0.77 to 3.88 , indicating low difficulty in most of the skills described in the questionnaire. However, the standard deviation was high on all items, indicating heterogeneity of responses among participants.

The main difficulties reported by students referred to the use of ICTs in items 22 "Use advanced search parameters as logical operators (and, or, not), filters, etc.", 30 "Install plugins (Flash, Shockwave, Java, etc.) required to access documents, photos, videos, and webpages", 33 "Compress and decompress files using specific software such as WinZip, WinRAR and others", 35 "Evaluate which program is needed for opening files of video and audio", and 37 "Convert text files from one extension to another".

All students (100\%) reported having personal computers and Internet access at home. Thus, professors can use ICTs for education in the classroom or in extra-class activities, having in mind, however, that some students may need training and technical support, particularly in relation to skills reported in the previous paragraph.

\section{Discussion}

Traditional types of education are increasingly being viewed as insufficient to handle the increased needs of health care workers. The use of ICTs is proving to be a valuable adjunct to improving students' learning (Knight \& Wood, 2005), the workforce and the population's health (Taylor, Abbott, \& Hudson, 2008).

However, despite the importance of ICTs and e-learning in health, its use is not an end in itself (Frehywot et al., 2013). Technology is just a delivery vehicle of instruction. What really seems to influence learning is the instructional strategy used (Parker, Bianchi, \& Cheah, 2008), which should be appropriate to the educational objectives and the characteristics of the students (Canto Filho et al., 2012), in order to lead them through meaningful activities (Lowther, Ross, \& Strahl, 2006).

Despite the growth of personal computers from 1980 we cannot assume that all students will be able to handle them perfectly. Although all students reported having a personal computer and Internet access at home, 
it was seen in this study that there is a great variability among students skills regarding the use of ICT. If such differences are not observed, the use of ICTs in education can produce undesirable effects (Verhoeven, Heerwegh, \& De Wit, 2010).

\section{Conclusions}

The scale obtained through factor analysis proved valid and reliable, with a one-factor structure, with excellent index of internal consistency and no loss of any items. Although the scale needs improvement incorporating abilities to handle new technologies used in educational contexts, such as podcasts, games, and augmented reality, the good psychometric indices constitutes already a contribution to the knowledge of the area.

Further studies will be necessary in order to optimize health student's learning processes, the training of the healthcare workforce and the high investments being made by universities in Brazil.

\section{References}

Bennett, S., Bishop, A., Dalgarno, B., Waycott, J., \& Kennedy, G. (2012). Implementing web 2.0 technologies in higher education: A collective case study. Computers \& Education, 59(2), 524-534.

Brasil. (2003). Ministério da Saúde, Secretaria de Gestão do Trabalho e da Educação em Saúde, Departamento de Gestão da Educação na Saúde. Caminhos para a mudança na formação e desenvolvimento dos profissionais de saúde: diretrizes da ação política para assegurar Educação Permanente no SUS. Brasília, DF, 2003.

Canto Filho, Alberto Bastos do, Ferreira, Luiz Fernando, Bercht, Magda, \& Tarouco, Liane Margarida Rockenbach. (2012). Objetos de aprendizagem no apoio à aprendizagem de engenharia: explorando a motivação extrínseca. Revista Renote. Novas tecnologias na educação, 10, 3 .

Chiu, C. M., Hsu, M. H., Sun, S. Y., Lin, T. C., \& Sun, P. C. (2005). Usability, quality, value and e-learning continuance decisions. Computers \& Education, 45(4), 399-416.

Creswell, J. W. (2010). Projeto de pesquisa: métodos qualitativo, quantitativo e misto. Porto Alegre: Artmed.

Frehywot, S., Vovides, Y., Talib, Z., Mikhail, N., Ross, H., Wohltjen, H., ..., Scott, J. (2013). E-learning in medical education in resource constrained low- and middle-income countries. Human Resources for Health, 11(4).

Guimarães, V. F. (2013). Análise do relacionamento entre autoeficácia no uso do computador e o impacto do treinamento no trabalho. 2013. (Doctoral dissertation, Instituto de Psicologia, Programa de pós graduação em psicologia social, do trabalho e das organizações, Universidade de Brasília). Retrieved from http://repositorio.unb.br/bitstream/10482/13678/1/2013_Vaness aFonsecaGuimaraes.pdf

Knight, J. K., \& Wood, W. B. (2005). Teaching more by lecturing less. Cell Biol Educ., 4(4), 298-310.

Kozma, R. B. (2003). Technology and classroom practices: An international study. Journal of Research on Technology in Education, 36(1), 1-14.

Kumar, S. (2009). Undergraduate perceptions of the usefulness of Web 2.0 in higher education: Survey development. The 8th European Conference on E-Learning (pp. 308-315). University of Bari, Italy. Retrieved from http://www.academicconferences.org/ecel/ecel2010/ecel09-proceedings.htm

Lorenzo, M. C. R., Garcia, M. L. S., \& Murias, T. F. (2010). Competencias necesarias para la utilización de las principales herramientas de Internet en la educación. Revista de Educación, 356, 483-507.

Lowther, D., Ross, S. M., \& Strahl, J. D. (2006). The influence of technology on instructional practices. International Journal of Knowledge, Culture and Change Management, 6. Retrieved from http://www.memphis.edu/crep/pdfs/The_Influence_of_ Technology.pdf

Parker, R. E., Bianchi, A., \& Cheah, T. Y. (2008). Perceptions of instructional technology: Factors of influence and anticipated consequences. Educational Technology \& Society, 11(2), 274-293.

Silveira, Luiza Helena Silva Dias, Maturano, Ediane Carolina Peixoto, Sousa, Helcimara Affonso, Viana, Delaine Gibeli, \& Bueno, Sonia Vilela (2012). Aprendizagem colaborativa numa perspectiva de educação sem distância. Revista Eletrônica Gestão \& Saúde, Esp, 1468-1478. 
Taylor, L., Abbott, P. A., \& Hudson, K. (2008). E-learning for health-care workforce development (IMIA Yearbook of Medical Informatics). Methods Inf. Med., Suppl. 1, 83-87.

Verhoeven, J. C., Heerwegh, D., \& De Wit, K. (2010). Information and communication technologies in the life of university freshmen: An analysis of change. Computers \& Education, 55(1), 53-66.

Westera, W. (2012). The eventful genesis of educational media. Education and Information Technologies, 17(3), 345-360.

World Health Organization. (2006). The World Health Report 2006-Working together for health. Retrieved from http://www. who.int/whr/2006/en/

WHO (World Health Organization). (2007). Task shifting to tacke health worker shortages. Retrieved from http://www.who. int/healthsystems/task_shifting_booklet.pdf

World Health Organization. (2013). Leveraging IT to address health workforce gaps-The alliance participates at the GET Health Summit. Retrieved from http://www.who.int/workforcealliance/media/news/2013/gethealthsummit2013/en/index.html 